\title{
INFLAMMATORY FIBROID POLYP. An immunohistochemical study
}

\author{
Gilda da Cunha SANTOS ${ }^{1}$, Venâncio A.F. ALVES ${ }^{3}$, \\ Alda WAKAMATSU ${ }^{3}$ and Sérgio ZUCOLOTO ${ }^{2}$
}

\begin{abstract}
Background - Inflammatory fibroid polyp is a localized lesion, which arises in the submucosa of the gastrointestinal tract, most often in the stomach.Although it is generally believed to represent a reactive, nonneoplastic condition, its histogenesis remains controversial. Aim - To study inflammatory fibroid polyp by immunohistochemistry in an attempt to further clarify their histogenesis. Material and Methods - Nine cases were studied by immunohistochemistry using a panel of antibodies against smooth-muscle actin, vimentin, S-100 protein, factor VIII- R.Ag and macrophage (HAM-56). Results - There was a strong diffuse positive staining pattern in the spindle cells with vimentin antibody. A patchy staining for smooth-muscle actin was observed in these cells. Immunophenotyping revealed a heterogeneous reaction with HAM-56. In edematous areas, HAM-56-positive cells show voluminous cytoplasm and reniform nuclei. In cell-rich areas, the HAM56-positive cells had fusiform cytoplasm. Stains for S-100 and factor VIII RAg were negative in the proliferating elements. Conclusions - The present immunohistochemical study refutes the suggested neural or vascular nature of the lesion. The strong positivity for vimentin in all cases suggests a major component of spindle cells best recognizable as fibroblasts. These results would favor the existence of a span of morphological and immunohistochemical patterns possibly indicating evolutive phases of an inflammatory reaction.
\end{abstract}

HEADINGS - Polyps. Immunohistochemistry. Gastric mucosa. Gastrointestinal diseases.

\section{INTRODUCTION}

Inflammatory fibroid polyp (IFP) is a rare sessile or pedunculated polypoid lesion of the gastrointestinal tract. Histologically it is composed of mesenchymal elements, loosely arranged collagen fibers, arterioles, blood and lymph capillaries and infiltration with eosinophilic leukocytes and lymphocytes, the latter being occasionally accumulated in rudimentary lymph follicles ${ }^{(28)}$.

Although it is generally considered to be a reaction to some form of inflammatory stimulant ${ }^{(2,6,8,14,16,24)}$, its histogenesis remains controversial. Immunohistochemical studies have largely refuted the previously suggested neural or vascular nature of the lesion by the negative staining for S-100 and

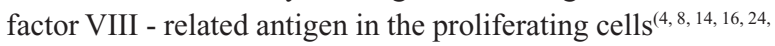
${ }^{25,29)}$. Other markers such as desmin, myoglobin and actin have been frequently negative, strongly suggesting that these cells are not smooth muscle cells ${ }^{(4,25,29)}$. The positivity for lysozyme, alpha 1-anti-trypsin, CD68 and anti-Factor XIIIa demonstrated in some cases has supported a histiocytic or a fibrohistiocytic nature of the lesion ${ }^{(1,25,27)}$. The results of some ultrastructural and immunohistochemical studies, however, did not detect the latter aspects and favoured the idea that the principal cells are fibroblasts or primitive mesenchymal cells ${ }^{(8,9,14,24,30)}$. Others have demonstrated the presence of fibroblastic, myofibroblastic and histiocytic lines of differentiation in the main cellular component $t^{5}$, ${ }^{12)}$. Recently, it was suggested that inflammatory fibroid polyps with concentric stromal proliferations may originate from a subpopulation of dendritic intersticial cells ${ }^{(10)}$.

In this study, nine IFPs were characterized immunohistochemi cally using a panel of antibodies in an attempt to solve the controversies surrounding their histogenesis.

\section{MATERIALS AND METHODS}

Nine cases of IFP of the gastrointestinal tract were analyzed. Three cases were collected from the files of the Department of Pathology of the University Hospital, Faculty of Medicine of Ribeirão Preto, University of São Paulo and another six cases from private laboratories of Ribeirão Preto, SP, and Aracaju, SE. Clinical information was obtained from surgical pathology reports. All tissues had been fixed in formalin and embedded in paraffin. In addition to hematoxylin-and-eosin-stained slides, sections were prepared from paraffin blocks for immunohistochemical stains.

Immunostaining was performed on deparaffinized sections using an immunoperoxidase method with the avidin-biotin amplification system as previously described ${ }^{(7)}$. A panel of immunohistochemical reactions was performed on a selected block in each case. The

\footnotetext{
${ }^{1}$ Department of Pathology - School of Medicine, Federal University of São Paulo; ${ }^{2}$ Division of Pathology, Adolfo Lutz Institute, São Paulo, SP, Brazil; ${ }^{3}$ Department of Pathology - Faculty of Medicine of Ribeirão Preto, University of São Paulo, Ribeirão Preto, SP, Brazil.

Address for correspondence: Dra. Gilda da Cunha Santos - Departamento de Patologia - EPM - UNIFESP - Rua Botucatu, 740 - Vila Clementino - 04123-900 - São Paulo, SP, Brazil. E-mail: gildacunha@uol.com.br
} 
specimens were deparaffinized in xylene and rehydrated. Endogenous peroxidase was blocked with $6 \% \mathrm{H}_{2} \mathrm{O}_{2}$ in methanol for 5 minutes. The primary antibodies, sources and dilutions used are listed in Table 1. All primary antibodies were incubated overnight at $+4^{\circ} \mathrm{C}$ and were sequentially followed by biotinylated rabbit-antimouse or goat-antirabbit IgG antiserum for 30 minutes at $37^{\circ} \mathrm{C}$ and then by a complex of avidin and biotinylated horseradish peroxidase (Vector Labs, USA) for $30 \mathrm{~min}$ at $37^{\circ} \mathrm{C}$. Careful rinses with several changes of phosphate-buffered saline were performed between each stage of the procedure. The reaction was developed with a solution of $60 \mathrm{mg} \%$ diaminobenzidine in Tris- $\mathrm{HCl}$ buffer, $\mathrm{pH} 7.4$, with $0.03 \% \mathrm{H}_{2} \mathrm{O}_{2}$ for 5 minutes in the dark.

TABLE 1 - Antibodies used in the immunohistochemical reactions

\begin{tabular}{ccccc}
\hline Antibodies & Clone & $\begin{array}{c}\text { Enzymatic } \\
\text { predigestion agent }\end{array}$ & Dilution & Source \\
\hline Vimentin & V9 & - & $1: 100$ & DAKO \\
$\begin{array}{c}\text { Smooth-muscle } \\
\text { actin }\end{array}$ & $1 \mathrm{~A} 4$ & - & $1: 1600$ & Sigma \\
S-100 protein & polyclonal & - & $1: 6000$ & DAKO \\
Macrophage & HAM- & Trypsin & $1: 2000$ & Enzo \\
& 56 & & & \\
Factor VIII-R.Ag & polyclonal & Trypsin & $1: 2000$ & DAKO \\
\hline
\end{tabular}

\section{RESULTS}

\section{Clinical findings}

The nine patients (Table 2) were five males and four females ranging in age from 35 to 58 years.

Signs and symptoms were abdominal pain (three cases), gastrointestinal intussusceptions (three cases), blood in stools (one case), pyrosis (one case) and vomiting (three cases). In one case, clinical information was not available.

The anatomical sites of the tumors were stomach-antrum (three cases), small bowel (three cases), cecum (one case) and colon (two cases).

TABLE 2 - Clinicopathologic features

\begin{tabular}{lccccc}
\hline Case & Age & Sex & Presenting symptoms & $\begin{array}{c}\text { Size } \\
(\mathrm{cm})\end{array}$ & Location \\
\hline 1 & 37 & F & Intussusception & 4.0 & Small bowel \\
2 & 48 & F & Abdominal pain and vomiting & 1.5 & Stomach (antrum) \\
3 & 29 & M & Intussusception & 2.0 & Small bowel \\
4 & 36 & M & Blood in stools & 2.5 & Colon \\
5 & 40 & M & Abdominal pain and vomiting & - & Cecum \\
6 & 50 & F & Abdominal pain and vomiting & 3.0 & Small bowel \\
7 & 35 & M & Unknown & 2.5 & Stomach (antrum) \\
8 & 58 & M & Intussusception & 3.5 & Colon \\
9 & 53 & F & Pyrosis & 1.8 & Stomach (antrum) \\
\hline
\end{tabular}

\section{Pathologic findings}

Gross features - The polyps ranged from 1.5 to $4.0 \mathrm{~cm}$ in greatest diameter. The polypoid lesions usually had a broad base and a tan or gray cut surface. The overlying mucosa usually showed foci of erosion. Microscopic features - Histologically there was a spectrum of features varying from case to case. The majority of the lesions consisted of mixed proliferation of spindle cells, loosely arranged in sweeping fascicles, or whorled structures with poorly defined margins, projecting into the lumen of the bowel. In cases with intact mucosa the mar- gin of the tumor was limited by muscularis mucosa, which was focally fragmented and infiltrated ( 2 and 7 ). The lesion usually filled the submucosa interrupting and splitting the muscle coats. In one case (8), the muscularis propria was partially replaced and even the subserosa was infiltrated. Prominent vascularity was noted in all polyps. Some vessels had the appearance and caliber of arterioles and venules.

The lesions were predominantly composed of mononuclear spindleshaped cells, with abundant eosinophilic cytoplasm. These proliferating cells were relatively uniform exhibiting round or elliptic nuclei.

Some cases demonstrated the full spectrum of morphologic patterns, ranging from histiocytoid cell populations suspended in a myxoid, edematous estroma with a prominent, delicate vasculature to elongated or spindled cell elements arranged in fascicles occasionally merged with hyalinized areas. In only one case the fascicles concentrically were arranged around vessels. The inflammatory cell infiltrate was composed predominantly of eosinophils, small lymphocytes, plasma cells, macrophages and scattered neutrophils (Figure 1). Hemorrhagic foci were noted in some polyps and hemosiderin was present within macrophages.

\section{Immunohistochemical findings}

There was a strong diffuse positive staining pattern in the spindle cells with vimentin antibody (Figure 2). A patchy staining for smooth-muscle actin (Figure 3) was observed in these cells. However, it was strongly positive around blood vessels. A heterogeneous reaction was observed with macrophage (HAM-56) antibody. Although immunophenotyping revealed HAM-56-positive cells, their morphological pattern was rather variable. In edematous areas, the HAM-56-positive cells showed voluminous, large cytoplasm and reniform nuclei. In cell-rich areas, the HAM-56-positive cells had fusiform cytoplasm and elongated nuclei (Figure 4). Stains for S-100 and factor VIII-related antigen were negative in the proliferating elements. Factor VIII-related antigen showed positivity in endothelial cells, demonstrating the great vascularity of the lesions. Some remaining nerve fibers were found to be $\mathrm{S}-100$ positive.

\section{DISCUSSION}

First described in 1949 by VANEK ${ }^{(28)}$ under the designation of "submucosal granuloma with eosinophilic infiltration", only a few series of cases of this condition submitted to immunohistochemical studies have been reported ${ }^{(1,5,8,10,12,14,16,24,26,27,29,30)}$. Various names have been used to refer to these rather pleomorphic benign lesions ${ }^{(22)}$, although the term "inflammatory fibroid polyp", proposed by HELWIG and RANIER ${ }^{(6)}$ has been the most cited. The present study includes one of the larger series in the literature, dealing with clinical and morphological patterns and especially with the immunohistochemical reactivity of spindle/stellate cells, in an attempt to further clarify their histogenesis.

Age, sex and clinical presentation were similar to those recorded in other series ${ }^{(24)}$. The polyp occurs most commonly in the stomach, generally in the antrum and less frequently in the ileum ${ }^{(9)}$. Clinical symptoms are variable depending on the location and size of the lesion. As in other reports, abdominal pain and intussusception, the latter almost always found with the small bowel polyp, are among the major symptoms ${ }^{(9)}$.

The lesions are most often found in the gastric antrum (about $70 \%$ of cases), followed by the small bowel (about $20 \%$ of cases) $)^{(3)}$.

Grossly, IFP generally presents as a solitary fibrous, grayish or yellowishgray mass of spherical or ovoid outline, commonly with ulceration of the 
mucosal surface ${ }^{(13)}$. Intra-lesional hemorrhage, present in some cases, although rarely mentioned, is assumed to be probably due to mechanical trauma in lesions localized in the small bowel with intussusception ${ }^{(24)}$

The polyp usually arises from the submucosal region and projects into the lumen of the bowel. The muscle coats may be infiltrated and destroyed ${ }^{(9,}$ 13,29). The penetration of the serous layer seen in one of our cases has been described in several papers ${ }^{(2,9,17,19,21,24,29)}$, and has been considered to be of no clinical significance, as demonstrated by the benign course $^{(24)}$.

At light microscopy, the differences in the amount of collagen fibers and the proportion of infiltrating cells may represent an evolutionary change ${ }^{(11,28)}$ the highly cellular lesion poor in collagen being the more recent one ${ }^{(28)}$.

The eosinophilia observed in many lesions has inevitably been a major subject of discussion by many authors. However, such an increase in the number of eosinophils should be interpreted with caution in view of the wide range of conditions in which it may be encountered $d^{(3,6,20)}$. In addition, eosinophils can usually be found in moderate number in the normal gastrointestinal mucosa ${ }^{(20)}$.

Another finding of IFP is the proliferation of small blood vessels. The role of this peculiar vascular structure with elongated cells in concentric layering around vessel has been likened to the pericyte and the pattern has been interpreted to be angiomatous ${ }^{(18,23)}$.A previous study has demonstrated the positive peroxidase reaction for muscle actin and "Ulex europeus" in the two main cellular components, supporting the conclusion that IFPs are lesions of vascular origin ${ }^{(26)}$. However, despite the non-staining of the fusiform cells for endothelial marker, our immunohistochemistry study also showed a rich vascularization of the lesion marked by positivity for factor VIII and smooth muscle actin on the wall of the vessels. These results may indicate a secondary participation of vascular proliferation, if one considers the lesion to be an inflammatory process. However, other authors reported a positivity of the spindle cells for CD 34 and suggested an origin from primitive perivascular or vascular cells ${ }^{(30)}$.

Recently, a study of 14 cases of IFP showed three cases nonreactive to CD 34. The cases positive for CD 34 had concentric stromal proliferations (CP). The authors concluded that IFP with CP may have different histogenesis from IFP without CP. It was also argued that IFP with CP may originate from a subpopulation of dendritic interstitial cells ${ }^{(10)}$.

From an ultra structural point of view, the histogenesis of IFP is controversial. The fusiform cells frequently found in the lesion have been considered to be fibroblasts ${ }^{(8,9,24)}$ or primitive mesenchymal cells exhibiting incomplete fibrohistiocytic differentiation ${ }^{(25,31)}$.

The present immunohistochemical study, like previous ones, has refuted the proposed neuronal or endothelial nature of the lesion, since spindle or stellate proliferating cells were found to be negative for S-100 and factor VIII-related antigen ${ }^{(4,5,8,14,16,24,25,29,30)}$. The positivity for lysozyme and alpha 1-anti-trypsin in earlier studies supports the histiocytic ${ }^{(1)}$ and fibrohisticytic nature of the lesion ${ }^{(25)}$. However, these are now considered to be rather nonspecific markers and a histiocytic/fibrohistiocytic differentiation was favored in another study since all the 10 cases were found to be positive to CD 68 through the monoclonal antibody KP-1, while factor XIII-related antigen was detected in six $(60 \%)^{(27)}$. In the present study, scattered, spindle-shaped and histiocytoid cells showed positivity to HAM-56 similar to a previous study ${ }^{(5)}$. These differences may be related to the functional or activated state of the cell, the former resembling fibroblasts and the latter being similar to histiocytes.

Only scattered spindle cells were stained by anti-actin antibody, thus indicating that the cell-rich areas contain at least a few spindle cells, possibly corresponding to myofibroblasts ${ }^{(15)}$, thus indicating a

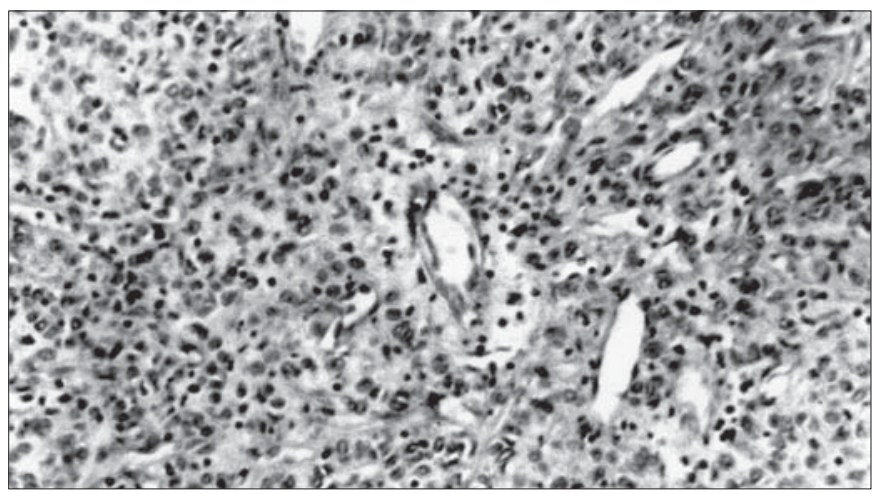

FIGURE 1 - IFP with spindle cells, richly vascularized stroma and inflammatory cells. H \& E. X125

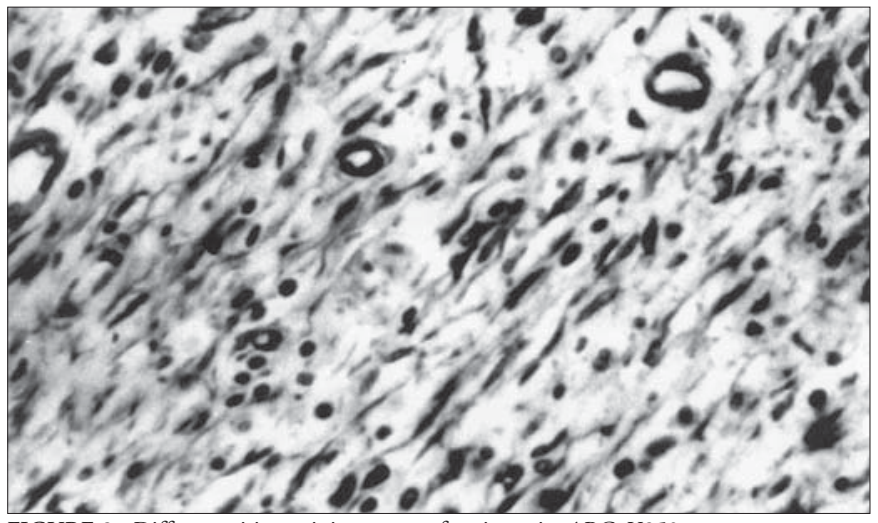

FIGURE 2 - Diffuse positive staining pattern for vimentin. ABC. X250

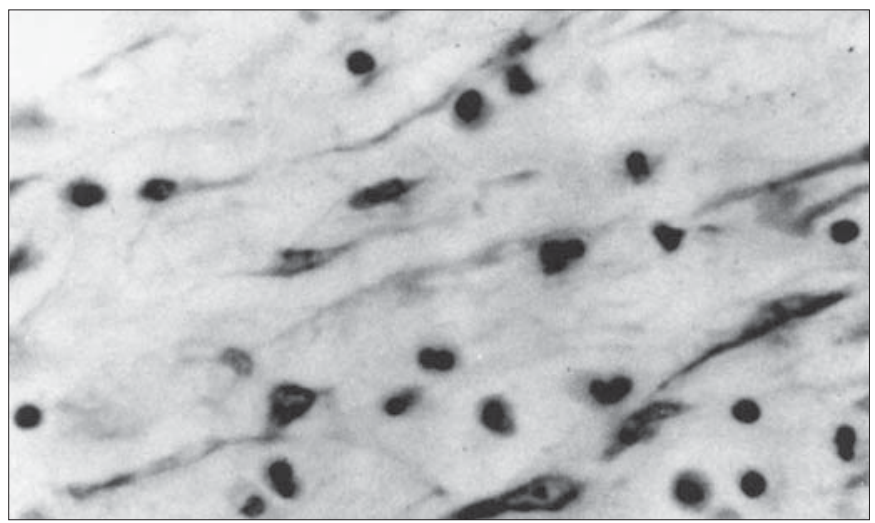

FIGURE 3 - Spindle cells positive for smooth-muscle actin. ABC. X400

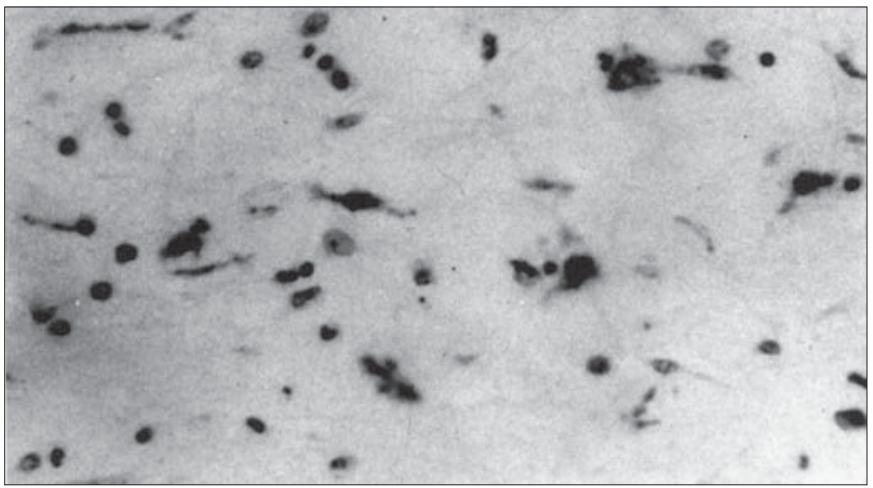

FIGURE 4 - HAM - 56 - positive fusiform cells. ABC X250 
heterogeneous immunophenotype of proliferating cells. Other results confirmed the presence of variable degrees of myofibroblastic histiocytic line of differentiation ${ }^{(5,12)}$.

The strong positivity for vimentin in all cases even in the absence of HAM56 expression suggests a major component of spindle cells best recognizable as fibroblasts. Each morphological pattern may be considered a phase of an inflammatory reaction, and the presence of inflammatory cells in variable number, especially eosinophils and macrophages, favors this hypothesis.

\section{ACKNOWLEDGEMENTS}

The authors would like to thank Drs. Nestor Piva, José Carlos Prates Campos, Dayr K. Kazava, Margarida M.F.S. Moraes and Catarina Shaletich for making available histological material from cases 4, 5, 6, 7, 8 and 9, Mrs Laura Midori Kawasse for laboratory assistance and Márcia Aparecida Oliva Destido for typing the manuscript.

Santos GC, Alves VAF, Wakamatsu A, Zucoloto S. Pólipo inflamatório fibróide. Estudo imunoistoquímico. Arq Gastroenterol 2004;41(2):104-7.

RESUMO - Racional - O pólipo inflamatório fibróide é uma lesão localizada que se origina na submucosa do trato gastrointestinal, mais freqüentemente do estômago. Embora se acredite que represente condição reativa e não neoplásica, sua histogênese permanece controversa. Objetivo - Estudar o pólipo inflamatório fibróide por imunoistoquímica na tentativa de contribuir para o entendimento de sua histogênese. Pacientes $\boldsymbol{e}$ Métodos - Foram estudados nove casos por imunoistoquímica usando-se um painel de anticorpos contra actina de músculo liso, vimentina, proteína S-100, fator VIII e macrófago (HAM-56). Resultados - Houve um padrão difuso de coloração nas células fusiformes, fortemente positivo para vimentina. Um padrão focal de positividade para actina de músculo liso foi observado nessas células. O estudo revelou reação heterogênea com HAM-56. Nas áreas edematosas, as células positivas para HAM-56 mostraram citoplasma volumoso e núcleos reniformes. Nas áreas ricamente celulares, as células positivas para HAM-56 apresentaram citoplasma fusiforme. As reações para S-100 e fator VIII foram negativas nos elementos proliferantes. Conclusões - O presente estudo imunoistoquímico afasta a hipótese de natureza neural ou vascular da lesão. A forte positividade para vimentina em todos os casos sugere um componente principal de células fusiformes, melhor reconhecidas como fibroblastos. Estes resultados favoreceriam a existência de um espectro de padrões morfológicos e imunoistoquímicos, indicando, possivelmente, fases evolutivas de uma reação inflamatória.

DESCRITORES - Pólipos. Imunoistoquímica. Mucosa gástrica. Gastroenteropatias.

\section{REFERENCES}

1. Anthony PP, Morris DS, Volwles KD. Multiple and recurrent inflammatory fibroid polyps in three generations of a Devon family: a new syndrome. Gut 1984;25:85462 .

2. Benjamin SP, Hawk WH, Turnbull RB. Fibrous inflammatory polyps of the ileum and cecum. Cancer 1977; 39:1300-5.

3. Blackshaw AJ, Levison RA. Eosinophilic infiltrates of the gastrointestinal tract. J Clin Pathol 1986;39:1-7.

4. Carlen B, Willen R. Inflammatory fibroid polyp of the ileum. Case report. Acta Chir Scand 1988;154:325-7.

5. Hasegawa T, Yang P, Kagawa N, Hirose T, Sano T. CD 34 expression by inflammatory fibroid polyps of the stomach. Mod Pathol 1997;10:451-6.

6. Helwig EB, Ranier A. Inflammatory fibroid polyps of the stomach. Surg Gynecol Obstet 1953;96:355-67.

7. Hsu SM, Raine L, Fanger H. Use of avidin-peroxidase complex $(\mathrm{ABC})$ in immunoperoxidase techniques: a comparison between $\mathrm{ABC}$ and unlabeled antibody (PAP) procedures. J Histochem Cytochem 1981;29:557-80.

8. Ishikura H, Sato F, Naka A, Kodama T, Aizawa M. Inflammatory fibroid polyp of the stomach. Acta Pathol Jpn 1986;36:327-35.

9. Johnstone JM, Morson BC. Inflammatory fibroid polyp of the gastrointestinal tract. Histopathology 1978;2:349-61.

10. Kim MK, Higgins J, Cho EY, Ko YH, Oh YL. Expression of CD-34, bcl-2, and kitinflammatory fibroid polyps of the gastrointestinal tract. Appl Immunohistochem Mol Morphol 2000;8:147-53.

11. Kim YI, Kim WH. Inflammatory fibroid polyps of the gastrointestinal tract: evaluation of histologic patterns. Am J Clin Pathol 1988;89:721-7.

12. Kolodziejczyk P, Yao T, Tsuneyoshi M. Inflammatory fibroid polyp of the stomach. A special reference to an immunohistochemical profile of 42 cases. Am J Surg Pathol 1993; 17:1159-68

13. LiVolsi VA, Perzin KH. Inflammatory pseudotumours (inflammatory fibrous polyps) of the small intestine. A clinicopathologic study. Am J Dig Dis 1975;20:325-36.

14. Mori M, Tamura S, Enjoji M, Sugimachi K. Concomitant presence of inflammatory fibroid polyp and carcinoma or adenoma in the stomach. Arch Pathol Lab Med 1988;112:829-32.

15. Mozzicato P, Azumi N, Leslie K. Expression of alpha actin and desmin in non-muscle sarcomas and sarcoma-like lesions [abstract]. Mod Pathol 1990;3:70A.
16. Navas-Palacios JJ, Colina-Ruizdelgado F, Sanchez-Larrea MD, Cortes-Causino J. Inflammatory fibroid polyp of the gastrointestinal tract: an immunohistochemical an electron microscopic study. Cancer 1983;51:1682-90.

17. Nkanza NK, King M, Hutt MSR. Intussusception due to inflammatory fibroid polyps of the ileum: a report of 12 cases from Africa. Br J Surg 1980;67:271-4.

18. Olsen EGJ, Wellwood JM. Hemangiopericytoma of the small intestine. Br J Surg 1970;57:66-9.

19. Ramirez AB, ReMine WH, Harrison EG. Inflammatory fibrous polyp (pseudotumor) of ileum. Postgrad Med 1973;54:107-13.

20. Salm RL. Gastric fibroma with eosinophilic infiltration. Gut 1965;6:85-91.

21. Samter TG, Alstott DF, Kurlander GF. Inflammatory fibroid of the gastrointestinal tract. Am J Clin Pathol 1966;45:420-35

22. Santos GC, Zucoloto S. Inflammatory fibroid polyp. Review of the literature. Arq Gastroenterol 1993;30:107-11.

23. Sawyer K, Lubchenco AE. Hemangioendothelioma of the stomach. Surgery 1951:30:383-7

24. Shimer GR, Helwig EB. Inflammatory polyps of the intestine. Am J Clin Pathol 1984;81:708-14.

25. Suster S, Robinson MJ. Inflammatory fibroid polyp of the small intestine: ultrastructural and immunohistochemical observations. Ultrasound Pathol 1990;14:109-19.

26. Trillo AA, Rowden G. The histogenesis of inflammatory fibroid polyps of the gastrointestinal tract. Histopathology 1991;19:411-6.

27. Van de Rijn M, Hendrickson MR, Rouse RV. An immunohistochemical study of inflammatory fibroid polyps of the gastrointestinal tract. Appl Immunohistochem Mol Morphol 1994;2:54-9.

28. Vanek J. Gastric submucosal granuloma with eosinophilic infiltration. Am J Pathol 1949;25:397-407.

29. Widgren S, Pizzolato GP. Inflammatory fibroid polyp of the gastrointestinal tract: ossible origin in myofibrobasts? A study of twelve cases. Ann Pathol 1987;7:184-92.

30. Wille P, Borchard F. Fibroid polyps of intestinal tract are inflammatory-reactive proliferations of CD 34-positive perivascular cells. Histopathology 1998;32:498-502.

31. Williams RM. An ultrastructural study of jejunal inflammatory fibroid polyp. Histopathology 1980;5:193-203. 